\title{
State of the science and the way forward for the ecotoxicological assessment of contaminated land
}

\author{
Roman G. Kuperman ${ }^{(1)}$, Ronald T. Checkai ${ }^{(1)}$, Marcos Vinicius Bastos Garcia(2), Jörg Römbke ${ }^{(3)}$, \\ Gladys L. Stephenson ${ }^{(4)}$ and José Paulo Sousa(5)
}

\begin{abstract}
${ }^{(1)}$ Edgewood Chemical Biological Center, Environmental Toxicology Branch, 5183 Blackhawk Road, Aberdeen Proving Ground, MD 21010-5424, USA. E-mail: roman.kuperman@us.army.mil, ron.checkai@us.army.mil (2)Embrapa Amazônia Ocidental, Caixa Postal 319, CEP69011-970 Manaus, AM, Brazil. E-mail: marcos.garcia@cpaa.embrapa.br ${ }^{(3)}$ ECT Oekotoxikologie GmbH, Böttgerstrasse 2-14, D-65439 Flörsheim, Germany. E-mail: J-Roembke@ectde ${ }^{(4)}$ Stantec, 70 Southgate Drive, Guelph ON N1G 4P5, Canada. E-mail: gladys.stephenson@stantec.com ${ }^{(5)}$ IMAR-Coimbra Interdisciplinary Centre, Departmento de Zoologia, Universidade de Coimbra, Largo Marquês de Pombal, P-3004-517 Coimbra, Portugal. E-mail: jps@zoo.uc.pt
\end{abstract}

\begin{abstract}
Over the past two decades, soil ecotoxicologists have made strides in utilizing the basic concepts and advancements in soil zoology and ecology. They have applied the existing tools, and developed new ones to investigate how chemical contamination can affect soil ecosystems, including the degradation or destruction of soil quality and habitats or the diminishment of belowground biodiversity. Soil ecotoxicologists are applying a suite of standard protocols, originally developed as laboratory tests with single chemicals (e.g., pesticides), and further enhancing both the approaches and protocols for the assessment of contaminated lands. However, ecological relevance of some approaches remains unresolved. The authors discuss the main challenges for a coherent ecotoxicological assessment of soil ecosystems amid contaminated lands, and provide recommendations on how to integrate the effects of physical and chemical soil properties, the variations in the diversity of soil invertebrates, and the interactions among organisms of various trophic levels. The review examines new international approaches and test methods using examples from three continents (in particular research conducted in Brazil), and provides recommendations for improving ecological relevance of ecotoxicological investigations of contaminated lands.
\end{abstract}

Index terms: contamination, ecological relevance, ecological risk assessment, soil pollution, terrestrial model ecosystems, toxicity tests.

\section{Estado da arte e perspectivas da avaliação ecotoxicológica de áreas contaminadas}

Resumo - Durante as últimas duas décadas, ecotoxicologistas de solo têm feito progressos ao utilizar conceitos básicos e avanços da zoologia e ecologia do solo. Os métodos existentes têm sido aplicados, e têm-se desenvolvido novas ferramentas para avaliar de que modo a contaminação química pode afetar o ecossistema terrestre, inclusive pela degradação ou destruição da qualidade do solo e dos habitats ou pela redução da biodiversidade edáfica. Os ecotoxicologistas de solo utilizam um conjunto de protocolos padronizados, originalmente desenvolvidos como testes de laboratório com compostos químicos simples como os pesticidas e, posteriormente, adaptados em termos de abordagens e métodos, para a avaliação de áreas contaminadas. No entanto, a relevância ecológica de algumas abordagens permanece questionável. Neste artigo, os autores discutem os recentes desafios para uma avaliação ecotoxicológica coerente do ecossistema solo em áreas contaminadas e apresentam recomendações de como integrar os efeitos das propriedades físicoquímicas do solo, as variações na diversidade de invertebrados do solo e, as interações entre organismos dos vários níveis tróficos. São analisadas novas abordagens e métodos de avaliação, usando-se exemplos de três continentes (particularmente o trabalho desenvolvido no Brasil), e são dadas recomendações de como aumentar a relevância ecológica na avaliação ecotoxicológica de áreas contaminadas.

Termos para indexação: contaminação, relevância ecológica, avaliação de risco ecológico, poluição do solo, modelo de ecossistemas terrestres, testes de toxicidade.

\section{Introduction}

Methodological approaches for ecological assessment of toxic chemicals stem from a series of workshops that established the hazard assessment paradigm (Cairns Junior et al., 1979). Focusing on the aquatic environment, this paradigm accentuated three basic concepts that shaped the development of subsequent ecological risk assessment methodology in the United States and elsewhere. These concepts stipulated that: the hazard posed by a chemical is a 
function of the magnitude of the exposure concentration relative to the toxicologically effective concentration; toxicity tests and studies of environmental transport and fate should be performed in tiers (from simple to more advanced studies); and as more tiers of testing are performed, uncertainty will decrease, while the magnitude of exposure and effective concentration will be refined further. This paradigm was adopted for assessing ecological risk of soil contamination in the United States after passing of the Superfund legislation in 1980. Later on, similar approaches were codified (The Canadian Council of Ministers of the Environment, 2006) or, at least, partly considered (Deutschland, 1998) in other industrialized countries. Superfund legislation gave impetus to the assessments of contaminated lands and to publication of laboratory methods for toxicological characterization of hazardous waste sites in the United States, which included the earthworm survival test (Greene et al., 1989). This test was an adaptation of a standardized Organisation for Economic Co-operation and Development (1984) method, which originally was developed for testing of single chemicals. The principal modification by Greene et al. (1989) of the OECD method was the use of a dilution series with site soil, which allowed testing the combined effects of chemical mixtures and soil physicochemical properties at a specific contaminated site. The use of a dilution series was later recognized by the International Organization for Standardization (1993).

Following the acceptance of a soil dilution series approach, efforts to develop more comprehensive strategies for ecological risk assessment of contaminated lands, using soil invertebrate and plant test species, were initiated in Europe. The focus of the OECD, with few exceptions, was on developing methods for single chemical testing, while the ISO focused on developing tests for the evaluation of contaminated soil. Thus, over the past two decades, a concerted effort has been made by soil ecotoxicologists to incorporate and apply basic concepts and advancements in soil zoology and ecology into the development of ecotoxicity assessment tools. They have applied the existing tools and developed new ones to investigate how chemical contamination can affect soil ecosystems, including the degradation or destruction of soil quality and habitats, the diminishment of belowground biodiversity, and the assessment of adverse impacts on complex food webs and the associated aboveground biotic communities.
Notwithstanding some methodological advancements (e.g., the inclusion of chronic endpoints such as reproduction), the existing plethora of standardized soil invertebrate-based tests focuses on assessing soil contamination effects via spiking soils with chemicals. The contemporary list of such tests covers several species of soil invertebrates (International Organization for Standardization, 2003a). These standardized tests were optimised for quantifying the exposure effects on survival and reproduction endpoints of test species in formulated artificial soil (Organisation for Economic Co-operation and Development, 1984). These tests have gained wide international acceptance among ecotoxicologists, risk assessors, and regulators because they provided a framework for acquisition of consistent toxicological data that were amenable for inter-laboratory comparison. The inclusion of test validity criteria in standardized protocols further enhanced the quality and reliability of toxicological benchmarks established in such tests.

While standardized soil invertebrate toxicity tests are useful for many purposes, including the derivation of trigger values for an initial general evaluation of a site, they lack ecological relevance for ecological risk assessment of contaminated lands. This diminished ecological relevance stems from the key test components that made standardization possible in the first place, namely the use of artificial soil, specified test species, and the focus on a single-species-based assessment of exposure effects. The current challenge for soil ecotoxicology is to integrate the effects of physicochemical properties of natural soils (including site-specific bioavailability and toxicity of soil contaminants), variations in species diversity (and thus sensitivity) of soil invertebrates, as well as interactions among organisms belonging to various functional (trophic) and structural (e.g., community) levels of soil ecosystems, into a coherent toxicological assessment framework for soil ecosystems amid contaminated lands.

\section{State of the science of standardized toxicity tests with soil invertebrates}

Standardized toxicity tests applicable to the assessment of contaminated land have been developed for at least seven species representing five soil invertebrate groups (Table 1). Most of these tests are also available as OECD Guidelines, developed for 
assessing toxicity of individual chemicals spiked into artificial soil. All of these tests use homogenized soil, except a test with the earthworm Dendrodrilus rubidus proposed by Environment Canada (Environment Canada, 2007), which uses samples of boreal soil horizons reconstructed in test containers in proportions that mimic field conditions. Many important groups of soil invertebrates (e.g., isopods, diplopods, insects) are underrepresented or missing in this list. Except for oligochaetes and some collembolans, only limited information is available on ecological requirements of these invertebrate groups in natural soils (Jänsch et al., 2005a). While the majority of standardized toxicity tests with soil invertebrates include both acute (mortality) and chronic or sublethal (growth, reproduction, and behaviour) endpoints, all, except two, are single species tests. The two exceptions are the terrestrial soil-core microcosm test (ASTM International, 1993) and the earthworm field test (International Organization for Standardization, 1999b), both of which have the potential for assessing community level effects. However, the terrestrial soil-core microcosm test has rarely been used for the assessment of contaminated land, while the earthworm field test (International Organization for Standardization, 1999b) is used solely for the evaluation of indirect effects of pesticides. Therefore, the current state of the science of soil invertebrate toxicology and risk assessment can be characterised as lacking sufficient knowledge of the ecological relevance of toxicological data derived in standardized tests. Future scientific advancement and the improvement of ecological relevance of empirical data for contaminated land assessments would require: transitioning ecotoxicological research from the artificial soil-based testing to the use of natural soils for species exposures; expanding the existing list of test species, which were selected primarily on the basis of practical considerations, to include species that are geographically and ecologically representative of the location and conditions at the site; and supplementing single-species laboratory tests with community and ecosystem-level assessments.

\section{Consideration of soil properties for developing soil invertebrate toxicity data}

Chemical toxicity testing with soil invertebrates is performed either by using a formulated artificial soil (Organisation for Economic Co-operation and Development, 1984) or a natural soil selected on the basis of the specific objectives of individual studies. Consequently, the test results depend on the intrinsic physicochemical properties of the selected soil, which affect the performance of test species and the bioavailability of test chemical. In an attempt to study the effects of soil properties on test species performance parameters, Natal-da-Luz et al. (2008) used experimentally manipulated formulations of the original OECD artificial soil (70\% sand, $20 \%$ clay, $10 \%$ peat, and up to $1 \%$ calcium carbonate). This study focused on the effects of soil texture (approximate ranges: sand

Table 1. Standardized toxicity tests applicable to the assessment of soil toxicity using invertebrates as test organisms.

\begin{tabular}{|c|c|c|c|}
\hline Standardized toxycity tests & Reference & Test organisms & Endpoint \\
\hline ASTM E2172 & ASTM International (2001) & Caenorhabditis elegans (Nematoda) & Mortality \\
\hline ISO 11268-1 & $\begin{array}{l}\text { International Organization for } \\
\text { Standardization (1993) }\end{array}$ & Eisenia fetida, Eisenia andrei (Oligochaeta) & Mortality \\
\hline ISO $11268-2$ & $\begin{array}{l}\text { International Organization for } \\
\text { Standardization (1998) }\end{array}$ & Eisenia fetida, Eisenia andrei (Oligochaeta) & Reproduction \\
\hline ISO $11268-3$ & $\begin{array}{l}\text { International Organization for } \\
\text { Standardization }(1999 \mathrm{~b})\end{array}$ & Natural earthworm community & $\begin{array}{l}\text { Abundance, } \\
\text { Biomass, Diversity }\end{array}$ \\
\hline ISO 16387 & $\begin{array}{l}\text { International Organization for } \\
\text { Standardization (2004) }\end{array}$ & $\begin{array}{l}\text { Enchytraeus albidus, Enchytraeus crypticus } \\
\text { (Oligochaeta) }\end{array}$ & Reproduction \\
\hline ISO $17512-1$ & $\begin{array}{l}\text { International Organization for } \\
\text { Standardization (2008a) }\end{array}$ & Eisenia fetida, Eisenia andrei (Oligochaeta) & Behaviour \\
\hline ISO 15952 & $\begin{array}{l}\text { International Organization for } \\
\text { Standardization (2006) }\end{array}$ & Helix aspersa (Mollusca) & Growth \\
\hline ISO 11267 & $\begin{array}{l}\text { International Organization for } \\
\text { Standardization (1999a) }\end{array}$ & Folsomia candida (Collembola) & Reproduction \\
\hline ISO $17512-2$ & $\begin{array}{l}\text { International Organization for } \\
\text { Standardization }(2008 \mathrm{~b})\end{array}$ & Folsomia candida (Collembola) & Behaviour \\
\hline ISO 20963 & $\begin{array}{l}\text { International Organization for } \\
\text { Standardization }(2005)\end{array}$ & Oxythyrea funesta (Coleoptera) & Mortality \\
\hline ASTM E1197 & ASTM International (1993) & Terrestrial soil-core microcosm test & Various \\
\hline
\end{tabular}


42-89\%; clay 6-52\%) and organic matter (peat content range from 2 to $10 \%$ ) on the avoidance behavior of the earthworm Eisenia andrei or collembolan Folsomia candida. The results of these studies showed that: soil properties significantly affected the behavior of both species, which avoided soil formulations with extreme textures and very low organic matter (OM) content; and that the effects of soil properties were greater for the earthworms compared with collembolans (Natal-da-Luz et al., 2008). Recognizing the effects of soil properties on soil invertebrates and the need for improving ecotoxicological relevance of experimental data, the original formulation of OECD artificial soil was modified in the new OECD test guideline by lowering the peat content to $5 \%$, thus making the resulting formulation more representative of natural European arable soils (Organisation for Economic Co-operation and Development, 2008). In addition, a tropical artificial soil, consisting of the same component proportions, but using coir (e.g., ground coconut fiber) in place of peat, has been developed for testing the toxicity of chemicals with intended application in tropical regions (Garcia, 2004).

Despite improvements in the formulations of artificial soils, they remained surrogates of natural soils with limited utility (e.g., as negative control soils or reference soils) for ecotoxicological assessments of contaminated lands. Such assessments require the use of an uncontaminated reference site soil, either as an experimental control treatment or as substrate for the dilution of contaminated site soils. In many cases, these reference soils are not readily available at the sites under investigation, and risk assessors frequently resort to using a representative uncontaminated soil collected elsewhere. To alleviate this problem, and to generally improve ecological relevance of toxicological data for risk assessment, considerable efforts were undertaken in Europe to identify natural soil types having soil properties that are representative of the specified geographical regions of the European subcontinent. These soils became known as EUROSOILS (Gawlik et al., 2001).

The EUROSOIL concept was originally developed for the performance of standardized environmental fate tests and consisted of soils from six European sites. The selected soils covered a wide range of properties (e.g., texture, OM content, soil $\mathrm{pH}$ ) and represented contrasting chemical bioavailability conditions, which were expected to also affect the toxicity for exposed test species. In spite of the limited use of the EUROSOILS as control or test substrate for ecotoxicological testing, the list of EUROSOILS was continuously adjusted to accommodate new member states of the European Union. An approach similar to the EUROSOIL concept has been taken by Environment Canada Department, which developed toxicity test methods for plant, earthworm, and soil arthropod species specifically for the assessment of contaminated lands. These methods included agricultural soils representing four different regions of Canada, and soils representing boreal forest, taiga, and tundra regions (Environmental Canada, 2007). Finally, in an attempt to define such reference soils for different regions in Brazil, Garcia (2004) proposed to use a specific natural soil (Tropical Natural Soil-TNS) from Central Amazonia for ecotoxicological testing purposes.

While the list of EUROSOILS continued to grow since its introduction in 1990 (Gawlik et al., 2001), it became clear that quantities of available EUROSOILS were insufficient for routine use in ecotoxicological research and risk assessment. Consequently, the EUROSOILS concept was modified to allow the use of any natural soil that was similar in key soil properties (i.e., texture, $\mathrm{pH}$, and $\mathrm{OM}$ content) to one of the EUROSOILS. This group of soils became known as SIM-Soils (Römbke \& Amorim, 2004). Practical experience suggests that this classification should be developed further by including biological parameters, such as the ability of soil to sustain the performance of standard test species.

\section{Performance of standard test species in uncontaminated soils}

Transitioning toxicity testing from reliance on exposures to contaminants in artificial soil to use of SIM-Soils with a wide range of properties has improved the ecotoxicological relevance of the test data. However, properties of some natural soils could be outside the tolerance thresholds for the soil invertebrate test species used in standardized OECD or ISO tests. Römbke et al. (2006b) investigated the performance metrics for some of these species, including E. andrei and $F$. candida in nine uncontaminated natural soils and OECD artificial soil (Table 2). Their studies revealed that reproduction of the test species varied greatly among the soils and was related to differences in soil 
properties, including texture, $\mathrm{OM}$ content, and soil $\mathrm{pH}$ (Figure 1). Soil properties also affected the reproduction but not the mortality of Enchytraeus albidus in a set of German and Portuguese field soils used by Amorim et al. (2005). Using soil types covering a wide range of European and North American soil properties, Kuperman et al. (2006) found similar effects of soil properties on the performance of three species of the genus Enchytraeus (E. albidus, E. crypticus, and E. luxuriosus). These studies showed that adult survival and juvenile production by E. albidus or E. luxuriosus were inhibited in acidic soils with $\mathrm{pH} \leq 5$, while less acidic soils having properties within the ranges $2.5-8.0 \% \mathrm{OM}, 6-26 \%$ clay, and $4-80 \%$ sand, could sustain survival and reproduction at or near validity criteria levels for the enchytraeid toxicity test (International Organization for Standardization, 2004). Performance of E. crypticus, in North American soils having properties within the ranges $1.2-42 \%$ OM, $1-29 \%$ clay, and 4.4-8.2 pH, met or exceeded all validity criteria (Kuperman et al., 2006). Similar results were found by Chelinho (2006) when testing different Mediterranean soils from Portugal, Spain, and Italy. The earthworm E. andrei did not reproduce in soils with OM content less than $2 \%$, and their reproduction was impaired in soils with extreme textures (sand content greater than $70 \%$, and clay content greater than $40 \%$ ). In contrast, E. crypticus was able to reproduce in all of the soils tested, fulfilling the test validity criteria (International Organization for Standardization, 2004). Production of juveniles by $F$. candida was highly variable in the same set of Mediterranean soils (Domene, 2007), but the International Organization for Standardization (1999a) validity criteria were met.
The overall experience, gained from studies with natural soils, shows clearly that the effects of soil properties on the performance metrics of common test species in natural soils should not be neglected. Therefore, the use of alternative test species that can consistently generate reproducible and reliable results should be considered for these soils. A set of new validity criteria will have to be developed for testing with these alternative species because their performance metrics are typically soil and species specific.

\section{Toxicity of chemicals to soil invertebrates in natural soils}

Accurate determination of the exposure risks for soil invertebrates at contaminated lands requires knowledge of contaminant/receptor relationships and the use of empirical models developed on the basis of such knowledge. The magnitude of chemical toxicity for soil invertebrates depends highly on interactions between the contaminant and soil properties. Bioavailability of metals was demonstrated to be one of the main factors determining the toxicity in soils (Allen, 2002; Chapman $\&$ Wang, 2000). Similarly, soil properties can affect the fate, transport, bioavailability, and subsequent toxicity of organic chemicals to soil invertebrates (Sousa et al., 2000; Amorim et al., 2002; Styrishave et al., 2008). Therefore, laboratory toxicity testing must take into account the influence of soil properties on chemical bioavailability, in order to more accurately assess the exposure risks for populations and communities of soil organisms in the field (Spurgeon \& Hopkin, 1995; Kuperman et al., 2006). However, too few studies have attempted to quantify the extent to which the different

Table 2. Physicochemical characteristics of the soils used in ecotoxicological tests (Römbke et al., 2006b) ${ }^{(1)}$.

\begin{tabular}{|c|c|c|c|c|c|c|c|c|c|}
\hline Soil $^{(2)}$ & $\begin{array}{l}\text { WHCmax } \\
\left(\mathrm{mL} \mathrm{kg}^{-1}\right)\end{array}$ & $\mathrm{pH}$ & OC & $\begin{array}{c}\mathrm{N} \\
---- \\
\end{array}$ & $\mathrm{C} / \mathrm{N}$ &  & Sand & $\begin{array}{c}\text { Silt } \\
---\% \text {-- }\end{array}$ & Clay \\
\hline OECD & 631 & 6.0 & 4.7 & 0.07 & 67.1 & 8.9 & 75.4 & 16.6 & 8.04 \\
\hline BRG & 601 & 4.9 & 2.34 & 0.29 & 8.1 & 14.1 & 13.6 & 56.7 & 29.7 \\
\hline BWZ & 307 & 3.8 & 1.54 & 0.05 & 30.8 & 3.3 & 81.3 & 13.6 & 5.1 \\
\hline ESo5 & 468 & 3.1 & 5.09 & 0.18 & 28.3 & 5.0 & 83.8 & 11.6 & 4.67 \\
\hline GGI & 232 & 5.5 & 0.94 & 0.06 & 15.7 & 2.0 & 80.5 & 15.7 & 3.82 \\
\hline HAG & 611 & 5.2 & 2.64 & 0.28 & 9.4 & 13.2 & 12.8 & 62.3 & 24.9 \\
\hline SBG & 653 & 5.8 & 3.37 & 0.33 & 10.2 & 11.8 & 27.0 & 47.1 & 25.9 \\
\hline SHA & 474 & 7.4 & 2.22 & 0.16 & 13.9 & 19.8 & 7.79 & 69.7 & 22.5 \\
\hline SOE & 483 & 6.6 & 1.63 & 0.16 & 10.2 & 13.8 & 1.97 & 83.0 & 15.0 \\
\hline St 2.2 & 500 & 6.1 & 2.7 & 0.19 & 14.2 & 7.9 & 76.9 & 16.3 & 6.84 \\
\hline
\end{tabular}

${ }^{(1)}$ Modified from Römbke et al. (2006b). Soils included nine natural field soils and OECD artificial soil. WHCmax, maximum water holding capacity; OC, organic carbon; CEC, cation exchange capacity. ${ }^{(2)}$ Abbreviations and locations of soils: OECD artificial soil (Organisation for Economic Co-operation and Development, 1984); BRG: Breddewarden, Lower Saxony; BWZ, Weitzgrund, Brandenburg; ESo5, Gudow, Schleswig-Holstein; GGI, Raddusch, Brandenburg; HAG, Frankfurt-Harheim, Hesse; SBG, Schmallenberg, North Rhine-Westphalia; SHA, Schafstädt, Saxony-Anhalt; SOE, Soest, North RhineWestphalia; St 2.2, LUFA 2.2 standard soil, Speyer, Rhineland-Palatinate; all locations are in Germany. 
soil parameters influence bioavailability or toxicity or have provided models that can predict chronic metal toxicity in a wide range of soils (Lock \& Janssen, 2001; Daoust et al., 2006).

Römbke et al. (2006b) investigated the effects of zinc nitrate on the survival and reproduction of earthworms and springtails in the soils described in Table 2. The results of the tests with collembolan $F$. candida showed that the soil properties influenced the toxicity, strongly and independently of the endpoint

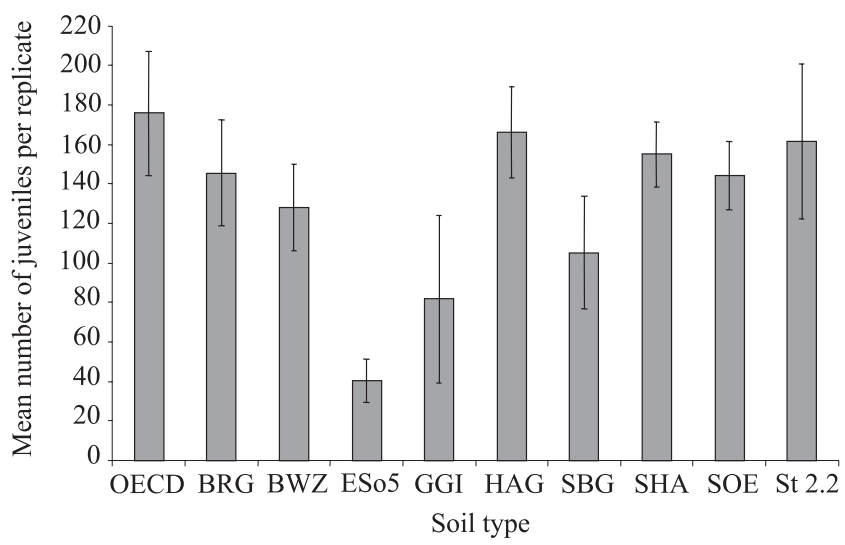

Figure 1. Production of juveniles by the earthworms (means and standard deviations), in the OECD artificial soil, and in nine natural soils (modified from Römbke et al., 2006b). For abbreviations and locations of soils see Table 2 . type (i.e., EC10 - 10\% effective concentration, or NOEC - nonobserved effect concentration; Table 3 ). The EC50 - median effective concentration - and the EC10 values differed by factors of 5 and 11 , respectively. The magnitude of the differences was similar to that for the earthworms exposed in those soils (Römbke et al., 2006b). More importantly, the results indicated that the EC50 values for either species determined in tests with OECD artificial soil were the second highest among all soils tested, which demonstrated clearly that relying exclusively on the toxicity estimates from OECD soil can underestimate potential exposure risk in the field. The relationships among soil properties and the toxicity benchmarks established in the collembolan tests were quantified by Römbke et al. (2006b) in an attempt to identify the key soil factors that affected zinc toxicity in those soils (Figure 2). The results of these analyses were equivocal. The toxicity of zinc to collembolans correlated inversely with soil $\mathrm{pH}$, which was consistent with results reported in the literature (Lock, 2002). In contrast, the relationships among the earthworm toxicity data and soil $\mathrm{pH}$, cation exchanger capacity (CEC), and organic carbon (OC) content remained unresolved.

Criel et al. (2008) investigated the chronic toxicity to E. fetida and F. candida of copper in 19 European soils, and demonstrated the importance of soil characteristics

Table 3. Effects of zinc nitrate on the reproduction of Folsomia candida exposed in OECD artificial soil or natural soils with contrasting properties ${ }^{(1)}$.

\begin{tabular}{|c|c|c|c|c|c|}
\hline Soil & $\begin{array}{c}\mathrm{EC} 10 \\
\left(\mathrm{mg} \mathrm{kg}^{-1} \mathrm{dw}\right)\end{array}$ & $\begin{array}{c}\text { EC50 } \\
\left(\mathrm{mg} \mathrm{kg}^{-1} \mathrm{dw}\right)(95 \% \text { confidence limits })\end{array}$ & $\begin{array}{c}\text { NOEC } \\
\left(\mathrm{mg} \mathrm{kg}^{-1} \mathrm{dw}\right)\end{array}$ & $\begin{array}{c}\text { LOEC } \\
\left(\mathrm{mg} \mathrm{kg}^{-1} \mathrm{dw}\right)\end{array}$ & $\begin{array}{c}\mathrm{MDD} \\
(\%)\end{array}$ \\
\hline OECD & 969 & $1,843(1,054-3,518)$ & $72(a)$ & $1,449(a)$ & $12(a)$ \\
\hline$\overline{\mathrm{BRG}}$ & 106 & 765 (ND) & 362(b) & $725(b)$ & $30(\mathrm{~b})$ \\
\hline BWZ & 256 & $394(384-405)$ & 181(a) & $362(a)$ & 17(a) \\
\hline ESo5 & 316 & $566(495-643)$ & 181(a) & $362(a)$ & 11(a) \\
\hline GGI & 1058 & 1274 (ND) & $725(b)$ & 1449(b) & $30(\mathrm{~b})$ \\
\hline $\mathrm{HAG}$ & 236 & $821(500-1,364)$ & 181(b) & $362(b)$ & $18(\mathrm{~b})$ \\
\hline SBG & 119 & 1,189 (ND) & 181(b) & $362(b)$ & 21(b) \\
\hline SHA & 840 & 2,065 (ND) & $362(b)$ & $725(b)$ & 17(b) \\
\hline SOE & 1,181 & $1,593(1,591-1,595)$ & $7,245(b)$ & 1,449 (b) & $22(\mathrm{~b})$ \\
\hline St 2.2 & 1,190 & $1,755(1,572-1,977)$ & $725(c)$ & $1,449(\mathrm{c})$ & $21(\mathrm{c})$ \\
\hline \multicolumn{6}{|l|}{ Statistics } \\
\hline Mean & 589 & 1,158 & 403 & 805 & 21 \\
\hline Min & 106 & 394 & 181 & 362 & 11 \\
\hline Max & 1,190 & 2,065 & 725 & 1,449 & 30 \\
\hline Factor & 11.2 & 5.2 & 4.0 & 4.0 & NA \\
\hline SD & 469 & 568 & 253 & 505 & NA \\
\hline CV $(\%)$ & 80 & 49 & 63 & 63 & NA \\
\hline Geometric mean & 406 & 1,023 & 335 & 671 & NA \\
\hline
\end{tabular}

${ }^{(1)}$ Modified from Römbke et al. (2006b). Concentration values are mg $\mathrm{Zn}\left(\mathrm{NO}_{3}\right)_{2} \mathrm{~kg}^{-1}$ dry soil weight; statistical comparisons are for OECD artificial soil (excluded from statistics)/natural soil pairings; EC50, median effective concentration; EC10, 10\% effective concentration; NOEC, nonobserved effect concentration; LOEC, lowest observed effect concentration; MDD, minimum detectable difference; ND, could not be determined; SD, standard variation; $\mathrm{CV}$, coefficient of variation; NA, not applicable. (a)Welch t test for inhomogeneous variances with Bonferroni adjustment; (b)Dunnett's t test for homogenous variances; (c)William's t test for homogenous variances. See Table 2, for abbreviations and locations of soils. 
for predicting copper toxicity to soil invertebrates. The results of this study established quantitative relationships that could be used for predicting copper
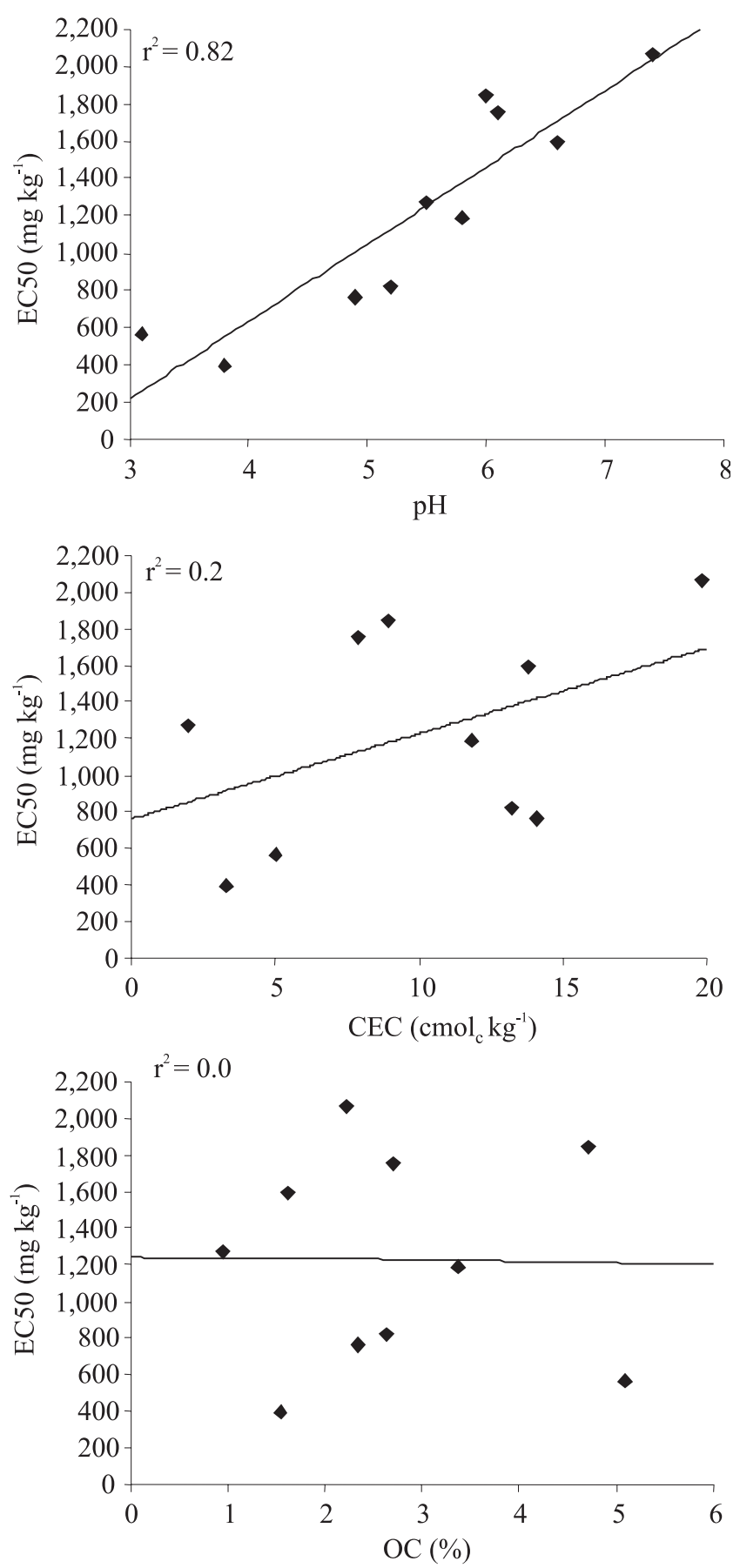

Figure 2. Relationships between zinc toxicity - median effective concentration (EC50) basis - to collembolan Folsomia candida, and soil pH (top); cation exchange capacity (CEC) (middle); and organic carbon (OC) content (bottom), determined in tests with nine natural soils and OECD artificial soil (modified from Römbke et al., 2006b). toxicity in a wide range of soils. Although there is a high probability that soil properties influence the fate and bioavailability of chemicals in soils and their concomitant toxicity to test species, the nature (i.e., the precise mechanisms) of this influence remains unclear.

\section{Test species relevant to geographical ecozones}

The importance of toxicity testing, with species that typically inhabit soils in the region where exposure to contaminants is expected, is gaining considerable recognition. The European Union (EU) now requires case-by-case decisions as part of the environmental risk assessment for genetically modified plants (GMPs) (Hilbeck et al., 2008). This includes the selection of test species relevant to the region where the GMP will be cultivated. However, even more important is the use of such species in the risk assessment of contaminated soil, which in most cases is site specific.

The following criteria have proven useful for the selection of soil invertebrate species as suitable test organisms: habitat - the species should occur in soils of the region of interest; frequency and abundance the species should frequently occur there in moderate to high numbers; origin - the species should occur in, and ideally be native to the region of interest; taxonomy - the species should be easy to identify; practicability - the species should be easy to handle (e.g. small body size) and reproduce in the laboratory all year round (preferably as a mass culture); stress tolerance - the species should have low sensitivity to environmental factors but be sensitive to soil contaminants.

These criteria were applied to data and information collected during a review of European ecological and ecotoxicological literature (Römbke et al., 2006c) to identify potentially useful soil invertebrate species, culturing techniques, and testing methods that are relevant to Canadian boreal forest, taiga, and tundra ecozones. Based on the analysis of the published data, earthworms, enchytraeids, collembolans, andpredatory mites were selected as the most promising candidates for ecotoxicological testing in Canadian boreal forest ecosystems. There were 320 invertebrate species or genera potentially inhabiting the soils of interest; 19 species were identified as suitable test organisms. Three species from each of the three key taxonomic groups of soil invertebrates (i.e., earthworms, collembolans, and mites) were proposed, together 
with additional species identified (enchytraeids, nematodes, predatory mites, and carabid beetles), for future test method development. The following list comprises the candidate test species proposed for test method development in Canada: earthworm species - Lumbricus rubellus (juveniles, epigeic/ adults, anecic), Dendrobaena octaedra (epigeic, litter dweller), Dendrodrilus rubidus (epigeic, litter dweller); Collembola species - Folsomia nivalis (Isotomidae),Hymenaphoruracocklei(Onychiuridae), Hymenaphorura similis (Onychiuridae); oribatid mites - Oppia nitens (Oppiidae), Pergalumna sp. (Galumnidae), Ceratozetes sp. (Ceratozetidae).

However, uncertainty remains regarding the sensitivities of these species to contaminants in comparison to those of the existing standard species. In other words: do we need ecozone-specific species for boreal forests? The results of preliminary attempts (Environment Canada, 2007) to address this question were inconclusive (Figure 3). For the earthworms and predatory mites, a direct comparison was not possible for different reasons. However, a median inhibiting concentration (IC50) of about 5\%, as reported for the test with the epigeic earthworm species D. rubidus, was indicative of high sensitivity. Differences between the IC50 values established for the two collembolan species were not statistically significant. Additional testing will be required before the relative sensitivities of the different species can be resolved.

\section{European Union efforts}

The role (particularly within a regulatory framework) of ecotoxicological tests in risk assessments of contaminated land has not been definitively resolved in the EU. However,

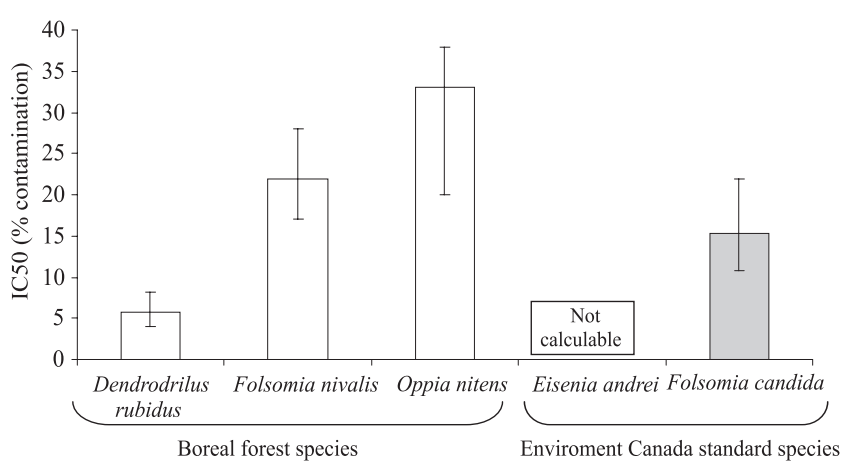

Figure 3. Toxicity - median inhibiting concentration (IC50) basis - of site soils contaminated with brine and petroleum hydrocarbons for three Canadian boreal forest species and two standard test species (Environment Canada, 2007). the available evidences - from the Netherlands (Rutgers et al., 2000) or Germany (Römbke et al., 2006a) -, provide strong justification for inclusion of ecotoxicological tests in site-specific evaluations, at least at higher tiers of the risk assessment process.

\section{Brazilian efforts}

Focusing on indirect effects of pesticides in the Amazon region of Brazil, Garcia (2004) used standard test species E. fetida and the isopod Porcellionides pruinosus, and tropical varieties of both species which were collected in the same region. The same criteria listed above were used to identify the following locally-occurring earthworm, woodlouse, and millipede species: Pontoscolex corethrurus (Müller, 1857) (Oligochaeta, Glossoscolecidae), Circoniscus ornatus (Verhoeff, 1941) (Isopoda, Scleropactidae), and Trigoniulus corallinus (Gervais, 1847) (Diplopoda, Pachybolidae).

Although all criteria concerning ecological relevance were satisfied, these species were difficult to culture in the laboratory, and their relative sensitivities to soil contaminants remain unknown. Nevertheless, the local species were used successfully in a limited number of laboratory tests and in the microcosm (terrestrial model ecosystem, TME) experiments (described below), which involve organisms collected from the field in sufficient numbers then added to the microcosms.

The five species were tested using existing standard test guidelines with some modifications. The native species were either as sensitive, or more sensitive to the fungicide carbendazim, compared with the standard test species (Table 4). However, the test results for the insecticide lambda-cyhalothrin indicated that native species were less sensitive compared with the standard test species. Based on these results and on the need for greater ecological relevance in toxicity assessments, it was recommended to standardize an isopod test (Jänsch et al., 2005b) and to include tests with locally important species into the risk assessment of pesticides. Additional research regarding the impacts of pesticides on the survival and reproduction of tropical soil invertebrates is needed before methods can be standardized for these test species.

\section{Assessment of the community/ecosystem-level effects in semi-field test systems}

Soil contamination can affect exposed invertebrates either directly, or indirectly, by altering specific interactions, and by disrupting soil food webs. 
However, single-species tests do not allow the assessment of interactions among soil invertebrate populations or determination of indirect effects of exposure to chemicals or mixtures of chemicals at a community level. Multispecies tests can establish data that enhance our understanding of the mechanisms by which soil contamination can affect the structure and function of soil ecosystems, thus considerably improve ecological relevance of the soil toxicity data for risk assessment at contaminated sites (Kuperman et al., 2002; Wentsel et al., 2003). Gunderson et al. (1997) suggested that a continuum of ecotoxicological responses at different time scales and across different levels of ecological organization should be considered in assessing ecological risk of soil contamination. Their conceptual framework established a chain of ecotoxicological evidence useful for assessing risk and provided a contextual matrix for multispecies semi-field tests. The expression "multispecies semi-field test" refers to a group of methods that were designed to assess the effects of chemicals at different levels of biological organization, generally between the population and the ecosystem levels, with a focus on community level responses. These methods attempt to combine the advantages of laboratory tests (e.g., reproducibility) and field studies (e.g., ecological realism), while striving for balance between precision and complexity of such investigations. According to Morgan \& Knacker (1994), these methods can be classified as follows. A - Model ecosystem segments ("microcosms"): assembled exposure units containing added species (usually nonindigenous). Testing with microcosms can be conducted under either controlled environmental conditions in the laboratory or ambient environmental conditions in the field. B - Ecosystem segments from the field ("mesocosms"): intact soil cores with indigenous communities; similarly to microcosms, testing with mesocosms can be conducted under either controlled environmental conditions in the laboratory or ambient environmental conditions in the field. $\mathrm{C}$ - Field enclosures: testing with enclosures can be conducted using either undisturbed soil with indigenous communities or with indigenous communities plus added species. Regardless of the type of community selected for testing, the field enclosure-based studies are conducted under ambient environmental conditions in the field.

Examples of multispecies assessments of chemical toxicity in soil using the three principal experimental approaches listed above are discussed below, in order to highlight both the advantages and challenges associated with the use of these methods. These examples include only studies that assessed the effects of a single chemical because no experimental data are currently available for using such approaches in toxicity testing of contaminated land.

\section{Model ecosystem segments ("microcosms")}

Soil microcosms, artificially assembled (gnotobiotic) units with added organisms, have been used to determine the effects of chemicals on the soil invertebrate community (Bogomolov et al., 1996; Kuperman et al., 2002; Burrows \& Edwards, 2004; Scott-Fordsmand et al., 2008). Experimental designs of the soil microcosm studies included assessments of the effects of pesticides and other organic contaminants on the indigenous invertebrate community, with or without the addition of test species from laboratory cultures. Using a soil microcosm technique, Kuperman et al. (2007) investigated the effects of sulfur mustard [HD, Bis-(2-chloroethyl) sulfide] in two soils with contrasting $\mathrm{OM}$ content and different abundance levels of indigenous microarthropod and nematode communities. The soil with low abundance levels was a Sassafras sandy loam (SSL; 50\% sand, 38\% silt, $12 \%$ clay, $4.9 \% \mathrm{OM}$, and $4.8 \mathrm{pH}$ ). The soil with high abundance levels was an oak-beech forest silt loam soil (FS; $33 \%$ sand, $56 \%$ silt, $11 \%$ clay, $16 \%$ OM, and $4.2 \mathrm{pH}$ ). The results of their studies showed that community level assessment and analysis of trophic

Table 4. The effects of two pesticides on tropical varieties of standard test species Eisenia fetida and Porcellionides pruinosus, and native Amazonian species Pontoscolex corethrurus, Circoniscus ornatus and Trigoniulus corallinus ${ }^{(1)}$.

\begin{tabular}{|c|c|c|c|c|c|}
\hline \multirow{2}{*}{$\begin{array}{l}\text { Test chemical } \\
\text { LC50 }\left(\mathrm{mg} \mathrm{kg}^{-1}\right)\end{array}$} & \multicolumn{2}{|c|}{ Earthworms } & \multicolumn{2}{|c|}{ Isopods } & \multirow{2}{*}{$\begin{array}{c}\text { Millipedes } \\
\text { T. corallinus }\end{array}$} \\
\hline & E. fetida & P. corethrurus & P. pruinosus & C. ornatus & \\
\hline Carbendazim & $>1,000$ & 45.6 & $>1,000$ & $>1,000$ & 503.5 \\
\hline Lambdy-cyhalothrin & 23.8 & 40.2 & 0.2 & 2.3 & 1.2 \\
\hline
\end{tabular}

(1)Modified from Garcia (2004). Concentration values are $\mathrm{mg}$ a.i. $\mathrm{kg}^{-1}$ dry soil weight (dw) for median lethal concentration (LC50); tests were performed at $28^{\circ} \mathrm{C}$ and in tropical artificial soil (TAS) to optimize the exposure effects for tropical conditions. 
structure of soil fauna using a microcosm assay were sufficiently sensitive to quantify chemical toxicity. Responses by different soil invertebrate groups to chemical exposure were specific to the soil ecosystems (Table 5). Differential toxicity of HD to the nematode and microarthropod communities demonstrated that chemical bioavailability can affect the toxicity to these groups of soil invertebrates. Toxicity of water-insoluble HD was considerably lower for nematodes, which inhabit soil pore water and water films surrounding soil particles, compared with microarthropods, which occupy soil surfaces in air-filled soil pores and thereby potentially receive greater exposure to HD. Therefore, these results showed that microcosms can be used to assess different exposure routes to soil contaminants by selecting invertebrate groups, which provide information on chemical bioavailability and toxicity in different soil microsites (e.g., the water film around soil particles, and air-filled soil pores). The authors concluded that laboratory microcosms can bridge the gap between single-species laboratory tests and field studies, and provide the means for validating the ecotoxicity data established in standardized single-species tests.

Ecosystem segments from the field ("mesocosms")

This type of multispecies testing involves the use of intact soil cores containing natural communities such as the terrestrial model ecosystem (TME) (Knacker et al., 2004). The TME is defined as a controlled, reproducible system that attempts to simulate the processes and interactions of components in a portion of the terrestrial environment (Sheppard, 1997). More specifically, TMEs are open (soil surface and plants are not separated from the surrounding atmosphere) and intact (soil is extracted from the field without disturbing the soil layers) systems. Usually, the soil cores have a diameter of about $17.5 \mathrm{~cm}$ and a length of $40 \mathrm{~cm}$. These dimensions can vary depending on the objectives of the study and on the individual soil properties. The intact soil cores are collected from the field with the help of a specially-designed steel extraction tube and a hydraulic excavator. In the laboratory, they are kept under controlled conditions for periods up to 16 weeks. Measurement endpoints are the abundance, biomass, and diversity of various soil organism groups, ranging from microbes to earthworms (enchytraeids are the most commonly assessed mesofauna group). In addition, functional endpoints like the feeding rate in bait-lamina tests or mass loss in decomposition studies can be determined, both under temperate (Förster et al., 2004) or tropical conditions (Förster et al., 2006).

Data in Figure 4 illustrate the effects of a single application of the fungicide carbendazim at four application rates, for a period of 16 weeks, on

Table 5. Toxicological parameters for different soil invertebrate groups (micro and mesofauna), derived from a microcosm study using oak-beech forest silt loam or Sassafras sandy loam soils amended with sulfur mustard [HD; Bis-(2-chloroethyl) sulfide] ${ }^{(1)}$.

\begin{tabular}{|c|c|c|c|c|}
\hline \multirow[t]{2}{*}{ Invertebrate group } & \multicolumn{2}{|c|}{ Oak-beech forest silt loam } & \multicolumn{2}{|c|}{ Sassafras sandy loam } \\
\hline & EC20 $\left(\mathrm{mg} \mathrm{kg}^{-1}\right)$ & $\begin{array}{ll}\text { EC50 } & \left(\mathrm{mg} \mathrm{kg}^{-1}\right)\end{array}$ & $\begin{array}{ll}\text { EC20 } & \left(\mathrm{mg} \mathrm{kg}^{-1}\right)\end{array}$ & $\begin{array}{ll}\text { EC50 } & \left(\mathrm{mg} \mathrm{kg}^{-1}\right)\end{array}$ \\
\hline Oribatida & 28 & 79 & 33 & 60 \\
\hline $95 \% \mathrm{CI}$ & $5-51$ & $49-110$ & $17-49$ & $45-75$ \\
\hline Prostigmata & 78 & 122 & 41 & 64 \\
\hline $95 \% \mathrm{CI}$ & $27-129$ & $28-217$ & $28-55$ & $54-74$ \\
\hline Mesostigmata & 11 & 46 & ND & 69 \\
\hline $95 \% \mathrm{CI}$ & $0-30$ & $7-85$ & ND & $67-73$ \\
\hline Collembola & 21 & 36 & 51 & 73 \\
\hline $95 \% \mathrm{CI}$ & $0-43$ & $18-54$ & $26-76$ & $30-117$ \\
\hline Total microarthropods & 42 & 71 & 41 & 65 \\
\hline $95 \% \mathrm{CI}$ & $29-56$ & $51-91$ & $31-51$ & $57-72$ \\
\hline Bacterivore nematodes & 207 & 282 & 52 & 108 \\
\hline $95 \% \mathrm{CI}$ & 149-264 & $243-323$ & $20-84$ & $79-136$ \\
\hline Fungivore nematodes & 250 & 270 & 87 & 123 \\
\hline $95 \% \mathrm{CI}$ & $18-481$ & $185-354$ & $62-112$ & $108-138$ \\
\hline Herbivore nematodes & 173 & 229 & 107 & 145 \\
\hline $95 \%$ CI & $150-196$ & $215-244$ & $82-132$ & $130-162$ \\
\hline Omnivore/Predator nematodes & 151 & 196 & 73 & 103 \\
\hline $95 \% \mathrm{CI}$ & $126-177$ & $185-208$ & $0-159$ & $53-154$ \\
\hline Total nematodes & 180 & 235 & 84 & 130 \\
\hline $95 \% \mathrm{CI}$ & $156-204$ & $220-250$ & 64-104 & $116-144$ \\
\hline
\end{tabular}

Pesq. agropec. bras., Brasília, v.44, n.8, p.811-824, ago. 2009 
the enchytraeid community in soils taken from a meadow site near Flörsheim (Germany) that were determined using the TME system (Moser et al., 2007). A multivariate statistical analysis of the data determined the rate-dependent decrease in the numbers of enchytraeids within the first four weeks after application (including a hormetic effect at the lowest rate), as well as recovery (at least partial; e.g., at the two lowest rates). The scale for taxon weight shown on the right side of Figure 4 identifies species (Henlea sp. plus various species of the genus Fridericia) that were disproportionally affected by carbendazim. Based on their ecological role in the community and on the potential effects of this fungicide on soil functions, Moser et al. (2007) concluded that the combined assessment of the effects on the enchytraeid community and the effects on the most sensitive taxa identified by means of a PRC (principal response curve), can be the most useful approach for evaluating data from the TME and other model ecosystems.

\section{Field enclosures}

Field enclosures are most often used in studies to assess the effects of pesticides on nontarget arthropods, e.g., carabid beetles (Candolfi et al., 2000). Therefore, these approaches will not be discussed in any further detail in this review.

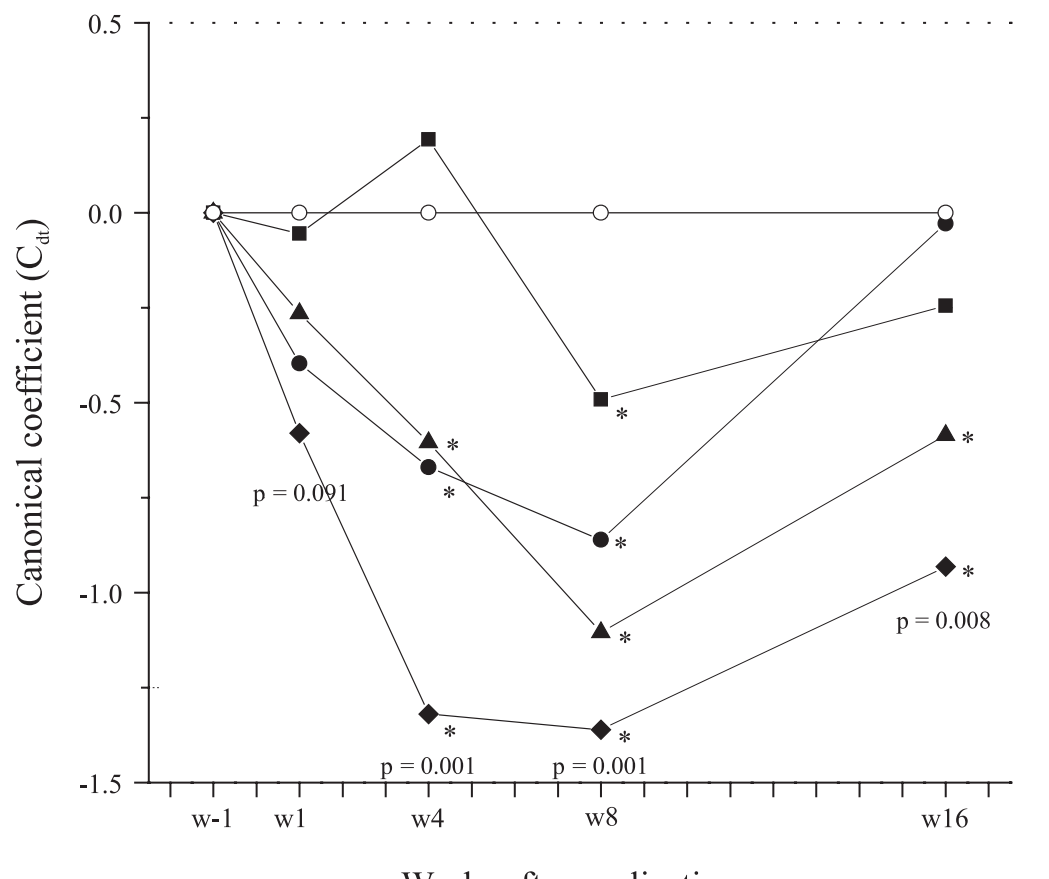

Weeks after application

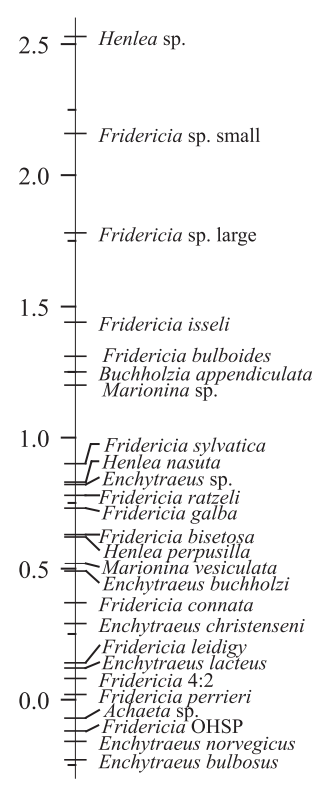

Taxon weight $\left(b_{k}\right)$

Figure 4. Principal response curves (PRC) for the effects of a single application of the fungicide carbendazim at four application rates, for a period of 16 weeks, on the enchytraeid community in soils taken from a meadow site near Flörsheim, Germany determined using the terrestrial model ecosystem (TME) test. Canonical coefficient $\left(\mathrm{C}_{\mathrm{dt}}\right)$ of the different application rates at the sampling points 1 to 16 (weeks after application), and the taxon weight $\left(b_{k}\right)$ for all taxa. Aplication rates: $\mathrm{kg}$ carbendazim ha-1. For each sampling point, the p-value (Monte Carlo permutation test; 999 permutations) for the comparison of all application rates is given. *Significant differences of the PCA sample scores compared to the control (Williams t-test; 2 -sided, $\mathrm{p} \leq 0.05$ ). The PRC-statistics show Eigenvalue (0.247), F-ratio (20.07), p-value (0,001) and explanatory (27.9) of the Monte Carlo permutation test (999 permutations) on significance of the $1^{\text {st }}$ canonical axis of the PRC and the explanatory content. Part of the total variance explained by time was 11.5 , and by treatment was 39.7. Percentage of the variance explained by treatment captured by de $1^{\text {st }}$ canonical axis of the PRC was 62.2 . 


\section{Conclusions}

Current approaches to the ecological risk assessment (ERA) of contaminated lands focus mainly on single-species laboratory tests developed for use with a few standard plant and soil invertebrate species and mixtures of the test soil with OECD artificial soil. The results of these tests are difficult to evaluate in ERA, because they lack ecological relevance to site-specific conditions in various aspects. The examples provided in this review showed clearly that improving ecological relevance in tiered testing strategies is possible in principle. However, before these approaches can be used routinely, the following actions are recommended: development of a standard set of natural soils representing different ecoclimatic regions, for use as reference soils in ERAs of contaminated lands (and, in the long term, also as standard soils for chemical toxicity testing); identification of relevant species for different geographical regions representing different ecozones, trophic levels, and taxonomic groups; and further refinement of multi-species semi-field methods, for evaluating community-level effects in soils.

\section{References}

ALLEN, H.E. Terrestrial ecosystems: an overview. In: ALLEN, H.E. (Ed.). Bioavailability of metals in terrestrial ecosystems: importance of partitioning for bioavailability to invertebrates, microbes, and plants. Pensacola: SETAC publication, 2002.

AMORIM, M.J. de B.; RÖMBKE, J.; SCHEFFCZYK, A.; SOARES, A.M.V.M. Effect of different soil types on the enchytraeids Enchytraeus albidus and Enchytraeus luxuriosus using the herbicide Phenmedipham. Chemosphere, v.61, p.1102-1114, 2005.

AMORIM, M.J. de B.; SOUSA, J.P.; NOGUEIRA, A.J.A.; SOARES, A.M.V.M. Bioaccumulation and elimination of ${ }^{14} \mathrm{C}$-Lindane by Enchytraeus albidus in artificial (OECD) and a natural soil. Chemosphere, v.49, p.323-329, 2002.

ASTM INTERNATIONAL. ASTM E2172:1-11: standard guide for conducting a laboratory soil toxicity test with the nematode Caenorhabditis elegans. West Conshohocken: ASTM International, 2001.

ASTM INTERNATIONAL. ASTM E1197:546-557: standard guide for conducting a terrestrial soil-core microcosm test. West Conshohocken: ASTM International, 1993.

BOGOMOLOV, D.M.; CHEN, S.K.; PARMELEE, R.W.; SUBLER, S.; EDWARDS, C.A. An ecosystem approach to soil toxicity testing: a study of copper contamination in laboratory microcosms. Applied Soil Ecology, v.4, p.95-105, 1996.

BURROWS, L.A.; EDWARDS, C.A. The use of integrated soil microcosms to assess the impact of carbendazim on soil ecosystems. Ecotoxicology, v.13, p.143-161, 2004.
CAIRNS JUNIOR, J.; DICKSON, K.L.; MAKI, A.W. Estimating the hazard of chemical substances to aquatic life. Hydrobiologia, v.64, p.157-166, 1979.

CANDOLFI, M.P.; BLÜMEL, S.; FORSTER, R.; BAKKER, F.M.; GRIMM, C.; HASSAN, S.A.; HEIMBACH, U.; MEAD-BRIGGS, M.; REBER, B.; SCHMUCK, R.; VOGT, H. Guidelines to evaluate side-effects of plant protection products to non-target arthropods. Darmstadt: IOBC/OILB Publication, 2000. 158p.

CHAPMAN, P.M.; WANG, F.Y. Issues in ecological risk assessment of inorganic metals and metalloids. Human and Ecological Risk Assessment, v.6, p.965-988, 2000.

CHELINHO, S. Selection of Mediterranean reference soils for ecotoxicological testing. 2006. 106p. Thesis (Master of Science) University of Coimbra, Coimbra.

CRIEL, P.; LOCK, K.; VAN EECKHOUT, H.; OORTS, K.; SMOLDERS, E.; JANSSEN, C.R. Influence of soil properties on copper toxicity for two soil invertebrates. Environmental Toxicology and Chemistry, v.27, p.1748-1755, 2008.

DAOUST, C.M.; BASTIEN, C.; DESCHÊNES, L. Influence of soil properties and aging on the toxicity of copper on compost worm and barley. Journal of Environmental Quality, v.35, p.558-567, 2006.

DEUTSCHLAND. Bundesministeriums der Justiz. BGB1. IS. 502.17. März 1998. Gesetz zum Schutz vor schädlichen Bodenveränderungen und zur Sanierung von Altlasten. Bundes-Bodenschutzgesetz. Bundesgesetzblatt, 17. März 1998.

DOMENE, X. Methodologies using soil organisms for the ecotoxicological assessment of organic wastes. 2007. 242p. Thesis (Ph.D.) - Autonomic University of Barcelona, Barcelona.

ENVIRONMENT CANADA. Validation of toxicology test methods for assessing petroleum hydrocarbons and brine spills in boreal forest soils. Otawa: Environmental Technology Centre, 2007. 42p.

FÖRSTER, B.; GARCIA, M.; FRANCIMARI, O.; RÖMBKE, J. Effects of carbendazim and lambda-cyhalothrin on soil invertebrates and leaf litter decomposition in semi-field and field tests under tropical conditions (Amazonia, Brazil). European Journal of Soil Biology, v.42, p.171-179, 2006.

FÖRSTER, B.; VAN GESTEL, C.A.M.; KOOLHAAS, J.E.; NENTWIG, G.; RODRIGUES, J.M.L.; SOUSA, J.P.; JONES, S.E.; KNACKER, T. Ring-testing and field-validation of a Terrestrial Model Ecosystem (TME) - an instrument for testing potentially harmful substances: effects of carbendazim on organic matter breakdown and soil fauna feeding activity. Ecotoxicology, v.13, p.129-141, 2004.

GARCIA, M. Effects of pesticides on soil fauna: development of ecotoxicological test methods for tropical regions. Bonn: University of Bonn, 2004. (Ecology and development series, 19).

GAWLIK, B.M.; LAMBERTY, A.; MUNTAU, H.; PAWELS, J. EUROSOILS - a set of CRMs for comparability of soil-measurements. Fresenius' Journal of Analytical Chemistry, v.370, p.220-223, 2001.

GREENE, J.C.; BARTELS, C.L.; WARREN-HICKS, W.J.; PARKHURST, B.R.; LINDER, G.L.; PETERSON, S.A.; MILLER, W.E. Protocols for short-term toxicity screening of hazardous waste sites. Washington: United States Environmental Protection Agency, 1989. 102p. 
GUNDERSON, C.A.; KOSTUK, J.M.; GIBBS, M.H.; NAPOLITANO, G.E.; WICKER, L.F.; RICHMOND, J.E.; STEWART, A.J. Multispecies toxicity assessment of compost produced in bioremediation of an explosives-contaminated sediment. Environmental Toxicology and Chemistry, v.16, p.2529-2537, 1997.

HILBECK, A.; JÄNSCH, S.; MEIER, M.; RÖMBKE, J. Analysis and validation of present ecotoxicological test methods and strategies for the risk assessment of genetically modified plants. Bonn: Federal Agency for Nature Conservation, 2008. 287p.

INTERNATIONAL ORGANIZATION FOR STANDARDIZATION. ISO 11267: soil quality - inhibition of reproduction of Collembola (Folsomia candida) by soil pollutants. Geneva: ISO, 1999a.

INTERNATIONAL ORGANIZATION FOR STANDARDIZATION. ISO 11268-1: soil quality - effects of pollutants on earthworms (Eisenia fetida). Part 1: determination of acute toxicity using artificial soil substrate. Geneva: ISO, 1993.

INTERNATIONAL ORGANIZATION FOR STANDARDIZATION. ISO 11268-2: soil quality - effects of pollutants on earthworms (Eisenia fetida). Part 2: determination of effects on reproduction. Geneva: ISO, 1998.

INTERNATIONAL ORGANIZATION FOR STANDARDIZATION. ISO 11268-3: soil quality - effects of pollutants on earthworms. Part 3: guidance on the determination of effects in field situations. Geneve: ISO, 1999b.

INTERNATIONAL ORGANIZATION FOR STANDARDIZATION. ISO 15799: soil quality - guidance for the selection and application of methods for the assessment of bioavailability of contaminants in soil and soil materials. Geneva: ISO, 2003.

INTERNATIONAL ORGANIZATION FOR STANDARDIZATION. ISO 15952: soil quality - effects of pollutants on juvenile land snails (Helix aspersa) - determination of the effects on growth by soil contamination. Geneve: ISO, 2006.

INTERNATIONAL ORGANIZATION FOR STANDARDIZATION. ISO 16387: soil quality - effects of pollutants on Enchytraeidae (Enchytraeus sp.). Determination of effects on reproduction and survival. Geneve: ISO, 2004.

INTERNATIONAL ORGANIZATION FOR STANDARDIZATION. ISO 17512-1: soil quality - avoidance test for determining the quality of soils and effects of chemicals on behaviour. Part 1: test with earthworms (Eisenia fetida and Eisenia andrei). Geneve: ISO, 2008a.

INTERNATIONAL ORGANIZATION FOR STANDARDIZATION. ISO 17512-2: soil quality - avoidance test for determining the quality of soils and effects of chemicals on behavior. Part 2: test with collembolans (Folsomia candida). Geneve: ISO, 2008 b.

INTERNATIONAL ORGANIZATION FOR STANDARDIZATION. ISO 20963: soil quality - effects of pollutants on insect larvae (Oxythyrea funesta) - determination of acute toxicity. Geneve: ISO, 2005.

JÄNSCH, S.; AMORIM, M.J.B.; RÖMBKE, J. Identification of the ecological requirements of important terrestrial ecotoxicological test species. Environmental Reviews, v.13, p.51-83, 2005 a.
JÄNSCH, S.; GARCIA, M.; RÖMBKE, J. Acute and chronic isopod testing using tropical Porcellionides pruinosus and three model pesticides. European Journal of Soil Biology, v.41, p.143-152, 2005 b.

KNACKER, T.; GESTEL, C.A.M. van; JONES, S.E.; SOARES, A.M.V.M.; SCHALLNASS, H.J.; FÖRSTER, B.; EDWARDS, C.A. Ring-testing and field-validation of a Terrestrial Model Ecosystem (TME) - an instrument for testing potentially harmful substances: conceptual approach and study design. Ecotoxicology, v.13, p.9-27, 2004.

KUPERMAN, R.; KNACKER, T.; CHECKAI, R.; EDWARDS, C. Multispecies and multiprocess assays to assess the effects of chemicals on contaminated sites. In: SUNAHARA, G.I.; RENOUX, A.Y.; THELlEN, C.; GAUDET, C.L.; PILON, A. (Ed.). Environmental analysis of contaminated sites. Chichester: John Wiley \& Sons, 2002. p.45-60.

KUPERMAN, R.G.; AMORIM, M.J.B.; RÖMBKE, J.; LANNO, R.; CHECKAI, R.T.; DODARD, S.G.; SUNAHARA, G.I.; SCHEFFCZYK, A. Adaptation of the enchytraeid toxicity test for use with natural soil types. European Journal of Soil Biology, v.42, p.234-243, 2006.

KUPERMAN, R.G.; PHILLIPS, C.T.; CHECKAI, R.T. Toxicity of chemical warfare agent HD (mustard) to the soil microinvertebrate community in natural soils with contrasting properties. Pedobiologia, v.50, p.535-542, 2007.

LOCK, K. Bioavailability and toxicity of metals to terrestrial organisms: extrapolation of laboratory experiments to field situations. 2002. Thesis (Ph.D.) - University of Gent, Gent.

LOCK, K.; JANSSEN, C.R. Test designs to assess the influence of soil characteristics on the toxicity of copper and lead to the oligochaete Enchytraeus albidus. Ecotoxicology, v.10, p.137-144, 2001.

MORGAN, E.; KNACKER, T. The role of laboratory terrestrial model ecosystems in the testing of potentially harmful substances. Ecotoxicology, v.3, p.213-233, 1994.

MOSER, T.; RÖMBKE, J.; SCHALLNAß, H.J.; VAN GESTEL, C.A.M. The use of the multivariate Principal Response Curve (PRC) for community level analysis: a case study on the effects of carbendazim on enchytraeids in Terrestrial Model Ecosystems (TME). Ecotoxicology, v.16, p.573-583, 2007.

NATAL-DA-LUZ, T.; RÖMBKE, J.; SOUSA, J.P. Avoidance tests in site-specific risk assessment - influence of soil properties on the avoidance response of Collembola and earthworms. Environmental Toxicology and Chemistry, v.27, p.1112-1117, 2008.

ORGANISATION FOR ECONOMIC CO-OPERATION AND DEVELOPMENT. Earthworm acute toxicity test. Paris: OECD, 1984. (Guideline for testing of chemicals, 207).

ORGANISATION FOR ECONOMIC CO-OPERATION AND DEVELOPMENT. Predatory mite (Hypoaspis (Geolaelaps) aculeifer) reproduction test in soil. Paris: OECD, 2008. (Guideline for testing of chemicals, 226).,

RÖMBKE, J.; AMORIM, M. Tackling the heterogeneity of soils in ecotoxicological testing: an euro-soil based approach. Journal of Soils and Sediments, v.4, p.276-281, 2004. 
RÖMBKE, J.; EISENTRÄGER, A.; HUND-RINKE, K.; JÄNSCH, S.; NEUMANN-HENSEL, H.; SCHALLNASS, H-J. Erprobung und Vorbereitung einer praktischen Nutzung ökotoxikologischer Testsysteme. Limburg: SIDUS-Verlag, 2006a. 372p.

RÖMBKE, J.; JÄNSCH, S.; JUNKER, T.; POHL, B.; SCHEFFCZYK, A.; SCHALLNASS, H. Improvement of the applicability of ecotoxicological tests with earthworms, springtails and plants for the assessment of metals in natural soils. Environmental Toxicology and Chemistry, v.25, p.776-787, 2006b.

RÖMBKE, J.; JÄNSCH, S.; SCROGGINS, R. Identification of potential organisms of relevance to Canadian boreal forest and northern lands for testing of contaminated soils. Environmental Reviews, v.14, p.137-167, 2006c.

RUTGERS, M.; FABER, J.H.; POSTMA, J.F.; EIJSACKERS, H. Site-specific ecological risks: a basic approach to the function-specific assessment of soil pollution. The Netherlands Integrated Soil Research Programme, v.28, p.1-18, 2000.

SCOTT-FORDSMAND, J.J.; MARALDO, K.; BRINK, P.J. van den. The toxicity of copper contaminated soil using a gnotobiotic Soil Multi-species Test System (SMS). Environment International, v.34, p.524-530, 2008.
SHEPPARD, S.C. Toxicity testing using microcosms. In: TARRADELlAS, J.; BITTON, G.; ROSSEL, D. (Ed.). Soil ecotoxicology. Boca Raton: Lewis Publications, 1997. p.345-373.

SOUSA, J.P.; LOUREIRO, S.; PIEPER, S.; FROST, M.; KRATZ, W.; NOGUEIRA, A.J.A.; SOARES, A.M.V.M. Soil and plant diet exposure routes and toxicokinetics of lindane in a terrestrial isopod. Environmental Toxicology and Chemistry, v.19, p.2557-2563, 2000.

SPURGEON, D.J.; HOPKIN, S.P. Extrapolation of the laboratory-based OECD earthworm toxicity test to metal-contaminated field sites. Ecotoxicology, v.4, p.190-205, 1995.

STYRISHAVE, B.; MORTENSEN, M.; KROGH, P.H.; ANDERSEN, O.; JENSEN, J. Solid-phase microextraction (SPME) as a tool to predict the bioavailability and toxicity of pyrene to the springtail, Folsomia candida, under various soil conditions. Environmental Science and Technology, v.42, p.1332-1336, 2008.

THE CANADIAN COUNCIL OF MINISTERS OF THE ENVIRONMENT. A protocol for the derivation of environmental and human health soil quality guidelines. Winnipeg: CCME, 2006. 186p.

WENTSEL, R.S.; BEYER, W.N.; EDWARDS, C.A.; KAPUSTKA, L.A.; KUPERMAN, R.G. Effects of contaminants on soil ecosystem structure and function. In: LANNO, R.P. (Ed.). Contaminated soils: from soil-chemical interactions to ecosystem management. Pellston: SETAC, 2003. p.117-159.

$\overline{\text { Received on October 31, } 2008 \text { and accepted on July 3, } 2009}$ 